\title{
Nest architecture, life cycle, and natural enemies of the neotropical leafcutting bee Megachile (Moureapis) maculata (Hymenoptera: Megachilidae) in a montane forest
}

\author{
William De O. SABINO ${ }^{1,2}$, Yasmine ANTONINI ${ }^{1}$ \\ ${ }^{1}$ Laboratório de Biodiversidade - Instituto de Ciências Exatas e Biológicas, Departamento de Biodiversidade, Evolução e \\ Meio Ambiente, Universidade Federal de Ouro Preto, Ouro Preto, Minas Gerais 35400-000, Brazil \\ ${ }^{2}$ Laboratório de Abelhas - Instituto de Biociências-Departamento de Ecologia, Universidade de São Paulo, São Paulo \\ 05508-900, Brazil
}

Received 4 May 2016 - Revised 24 November 2016 - Accepted 19 December 2016

\begin{abstract}
Studies on the nesting biology of cavity nesting hymenoptera (bees and wasps) have stimulated many questions related to the behavior, life cycle, trophic niche, and sex ratio to better understanding of the life history of insects. Leafcutting bees are common insects, and many are important and efficient pollinators of crops and other plants. We studied the nesting biology of Megachile (Moureapis) maculata in a montane semi-deciduous forest in Brazil using trap nests in order to improve the knowledge of aspects of the natural history of this important pollinator group. During 27 months, 87 nests were collected with an average of seven brood cells per nest. Most of the nests were in cavities of $0.9 \mathrm{~cm}$ in diameter (77\%), and the number of brood cells ranged from 1 to 11 . Absence of seasonality in nesting behavior suggests a multivoltine species. The total mortality rate was $26 \%$, with the cuckoo bee Coelyoxis (Acrocoelioxys) sp. being the main natural enemy attacking 15\% of brood cells. The sex ratio is clearly male-biased (1:0.42). Females and their brood cells were larger than males and their brood cells, which may suggest an imbalance in the energetic cost of each sex. The success of this bee species in colonizing trap nests makes it an interesting potential opportunity to use this species for pollination of cultivated Asteraceae plant species, like sunflower.
\end{abstract}

Atlantic forest / sex ratio / solitary bees / trap nests

\section{INTRODUCTION}

The genus Megachile Latreille, 1802 (Megachilidae) is large, with 1524 species described, of which 147 have been recorded from Brazil (Ascher and Pickering 2015). Species of megachilid bees use several nesting substrates. Some species dig nests in the soil, but most are specialists in using pre-existing cavities in the ground, among rocks or in pithy stems and galls

Corresponding author: W. Sabino, sabinobees@usp.br

Handling editor: Alexandra Klein
(Eickwort et al. 1981). Pre-existing cavities are also found in dead wood, such as old galleries of wood-dwelling beetles, which are important nest spaces in forest ecosystems (Zuo et al. 2016).

Materials used for nesting construction are quite diverse, including sand, mud, resins, plant trichomes, petals, and leaf pieces. The behavior of nesting in cavities probably evolved repeatedly in ancestral species that nested in the soil (Eickwort et al. 1981) and may be more common than once supposed. Females, particularly of the genus Megachile, use their mandibles to cut pieces of leaves used to build their brood cells. This remarkable behavior, of using pieces of leaves to build the brood cells, is unique among bees. 
Research using trap nests can reveal varied life stories in insects (e.g., Staab et al. 2014) and are helpful in studies of bioindicators (e.g., Tylianakis et al. 2004; Tscharntke et al. 1998). Unlike eusocial species, solitary bees spend much of their lifetime constructing and provisioning their nests. The environmental structure affects the choice of nesting site and food availability (Morato and Martins 2006).

Nests of solitary bees are also useful for the study of parental investment strategies since females (males do not participate in nest construction or provisioning) have a high degree of control over sex determination and the size of their offspring (Bosch 2008).

Many parasitoids attack nests of wasps and bees (e.g., Krombein 1967; Genaro 1996; Veddeler et al. 2010), and several insect groups have been recorded in association with nests of species of Megachile. Among the most common are the cleptoparasitic bees of the genus Coelioxys (Megachilidae) (Michener 1953; Krombein 1967; Yanega 1994; Zillikens and Steiner 2004) and chalcidoid wasps (Chalcidoidea; Peck 1969).

Megachile (Moureapis) maculata Smith, 1853 is a megachilid bee that occurs at higher altitudes (higher than $600 \mathrm{~m}$ ) and has been recorded in Argentina, Paraguay, and Brazil (Raw 2007). There is little information about the nesting biology of the subgenus Megachile (Moureapis). Laroca (1991) provided some data about nests of Megachile apicipennis Schottky, 1902 (cited as Pseudocentron apicipennis) while studying nests of Euglossa stellfeldi Moure, 1947. Buschini et al. (2009) studied the pollen in nests of an unidentified species of this subgenus. Teixeira et al. (2011) and Cardoso and Silveira (2012) described the nesting biology of Megachile benigna Mitchell, 1930, and Cardoso and Silveira (2012) also reported on some aspects of the nests of M. maculata, but based on only two nests.

The occurrence of M. maculata in trap nests was reported for the first time by Sabino and Antonini (2011) (cited as Megachile anthidioides Radoszkowski, 1874). Sabino et al. (2016) also performed a thorough study of the trophic niche of this species, showing it is oligolectic on Asteraceae. Despite the unique biology and economic importance of megachilid bees as pollinators of cultivated plant (Pitts-Singer and Cane 2011), the biology of the vast majority of species remains unknown. Here, we present the results of a 27-month study on the nesting behavior of Megachile (Moureapis) maculata and describe some aspects of its biology including nesting period, sex ratio, and natural enemies.

\section{MATERIALS AND METHODS}

Data were collected at the Parque Estadual do Itacolomi (from here on PEIT). The 7000-ha reserve is at $20^{\circ} 22^{\prime} 30^{\prime \prime} \mathrm{S}$ and $43^{\circ} 32^{\prime} 30^{\prime \prime} \mathrm{W}$ between a 650 and 1772-m elevation, in the historic districts of Ouro Preto and Mariana, state of Minas Gerais, Brazil. Regional climate is moderately humid subtropical with an annual average temperature of $21.7^{\circ} \mathrm{C}$. Local vegetation is mostly composed of montane tropical forest in various stages of regeneration (from an abandoned tea plantation) with large tracts of rocky fields on mountain tops (Messias et al. 1997).

Trap nests were made from black tubes (made of black cardboard) placed inside plastic bottles and black tubes inserted in wooden blocks with a total of 60 holes arranged linearly. Trap nests were uniform in length $(120 \mathrm{~mm})$, but varied in their inner diameters $(6,9,13$, and $16 \mathrm{~mm})$. Trap nests were tied horizontally to tree trunks at about $1.8 \mathrm{~m}$ above the soil surface and were set at 4-m intervals along a trail in an open field near forest. The same number of nests of each diameter was offered.

A total of 600 trap nests (150 of each diameter) were kept in the field between January 2007 and February 2008 and between March 2009 and March 2010. They were inspected twice a month. Tubes occupied by bee nests were collected, taken to the laboratory, and replaced with new empty tubes.

When a female was observed actively nesting (i.e., carrying leaves or pollen to the nest), the tube she was using was left in the field until the next inspection. We also actively searched for females on plants in order to discover which plant species they used to cut leaves from, for brood cell construction.

In the laboratory, each tube brought from the field was kept in a glass tube that was closed at both ends with a tissue (muslin) to allow air circulation and maintained at room temperature (ca. $15-25^{\circ} \mathrm{C}$ ). We measure the intertegular distance of the individuals that hatched (ID) with digital 
calipers. This measure was used to access body size, since it reliably correlates with body mass and is frequently used in studies of nesting biology, foraging ecology, and reproductive biology of bees (Cane 1987; Bullock 1999). We cubed the thorax width, as this has been shown to be highly correlated with dry weight (Martins et al. 1999; Oliveira and Schlindwein 2010). The secondary sex ratio was calculated as the number of hatched females per hatch male. Brood cells that remained closed for a long period of time (about 6 months) were opened to investigate whether an immature had died (egg or pre- or post-defecating larvae) or whether it was diapausing. The number and identity of parasitoids and kleptoparasites was also recorded. All insects were identified and deposited with their nest material in the Entomological Collection of the Laboratório de Biodiversidade, of the Universidade Federal de Ouro Preto.

The length and width of 187 leaves of 30 nests in trap nests of $9 \mathrm{~mm}$ in diameter and 55 leaves of 5 trap nests of $16 \mathrm{~mm}$ in diameter were measured with a digital caliper to evaluate if the size of the leaf used by females varies with nest tube diameter. These diameters were chosen because they are the most abundant $(9 \mathrm{~mm})$ and extreme $(16 \mathrm{~mm})$ diameter of tubes used for nesting. The $t$ test was used to compare pieces of leaves coming from nests of different diameters. All data are presented as mean \pm standard deviation.

A generalized linear model (GLM) (with a quasi-poison error distribution) with contrast analyses was performed to test for correlations between differences in male and female sizes, with length and diameter of cells and the number of built nests in the two seasons (wet and dry).

A GLM also was performed to test the parental investment, by comparing the body mass of male and female, produced in each nest, during the study period. The average body mass of males and females, in each nest, was used as the response variable and sex, month, and the interaction sex/month as the explanatory. Initially, a full model was fitted to the data, including all explanatory variables and their interactions. Terms were then removed from the full model by stepwise deletion (Crawley 1993). Whether the removal of a term caused a significant increase in deviance was assessed with a chi-squared test.
Mortality rates $(\%)$ were calculated in relation to the total number of finished brood cells. The Mann-Whitney test was used to evaluate whether there was a difference in nesting between the dry and rainy seasons (the rainfall data was provided by Novelis do Brasil) and whether there was a difference in development time between dry and wet seasons. Regression analysis was performed to evaluate if there was a relationship between food availability (richness of flowering plants and trophic niche breadth) and operational sex ratio. The number of emerging males and females was used as a dependent variable and trophic niche breadth as the independent variable. Data from flowering plants and trophic niche breadth (calculated monthly by the Shannon's diversity index, using the frequency of pollen grains found in brood cells) came from Sabino et al. (2016). Statistical analyses were made using Statistica 10.0.

\section{RESULTS}

\subsection{Nests collection and nesting activity}

A total of 344 adults emerged from the 87 occupied trap nests. Nesting activity occurred throughout both dry and rainy seasons with no significant differences in the number of occupied nests $(U=52 ; P>0.05$; Figure 1$)$. The bees built their nests in tubes of all four diameters $(6,9,13$, and $16 \mathrm{~mm}$ ), with $77 \%$ being built in $9-\mathrm{mm}$ diameter tubes (Figure 2).

The total number of specimens, the number and average size of females and males that emerged, and the sex ratio are presented in Table I. The total sex ratio was male-biased (1:0.42; Figure 3$)$ and differed significantly from $1: 1\left(\chi^{2}=56.98\right.$; $P<0.05$ ) (Table I). Body mass of the females is significantly higher than that of males $\left(F_{1,193}=308.50, P<0.05\right)$ (Table II); however, no significant differences were found among individuals of the same sex. Body mass did not change during the nesting period $\left(F_{15,178}=1.38\right.$; $P=0.15$ ) (Table II). Males hatched earlier, but occupied the innermost brood cells of each trap nest. No significant differences were found between the number of emerging males and females and flowering plant richness or trophic niche breadth. 


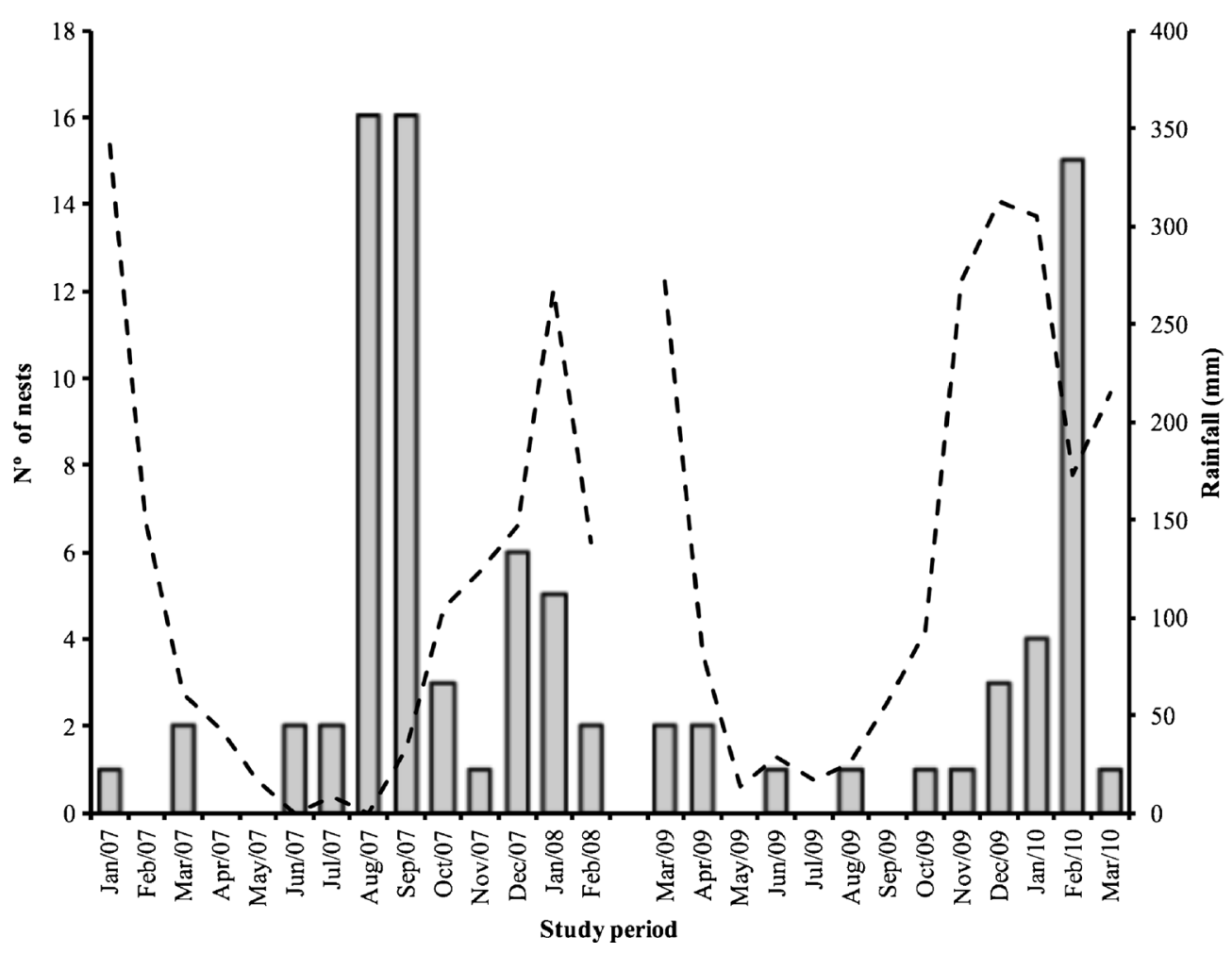

Fig. 1. Nesting patterns of Megachile (Moureapis ) maculata on trap nests during 30 months of study at the Parque Estadual do Itacolomi, Brazil.

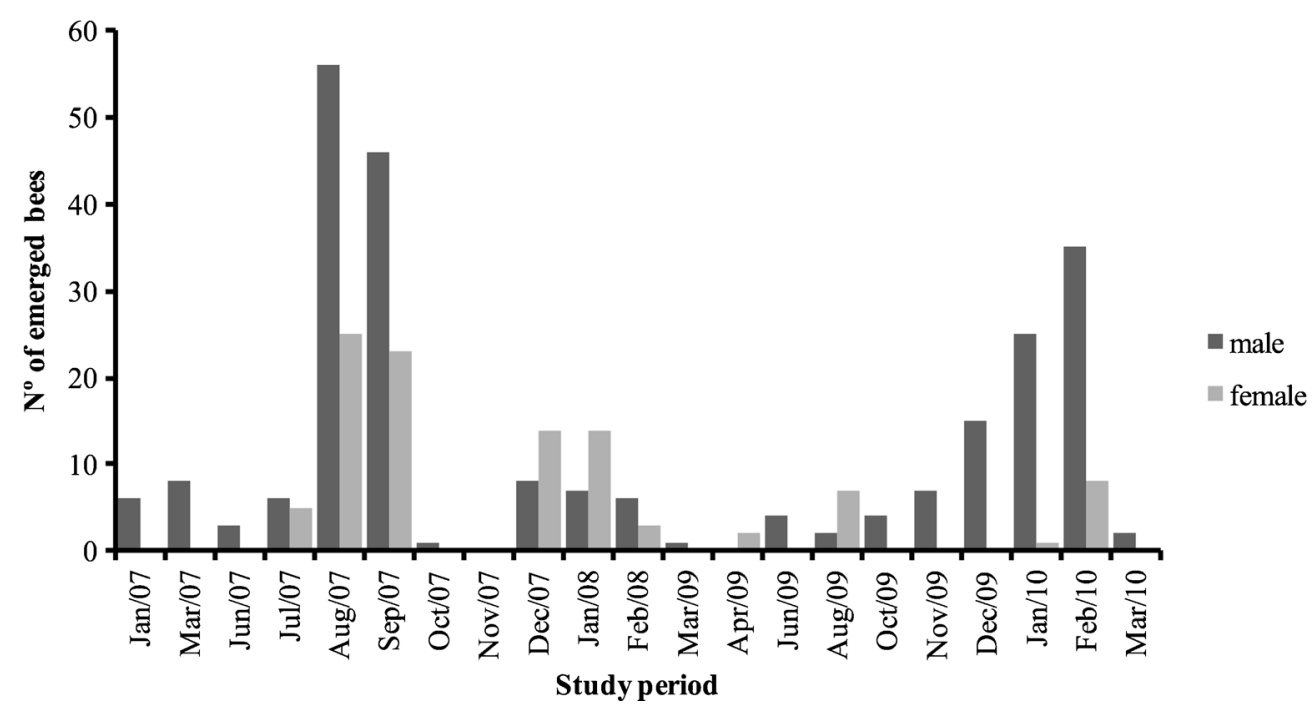

Fig. 2. Total number of males and females of Megachile (Moureapis) maculata hatched in the laboratory, throughout the sample period. The bees were collected through trap nests between January 2007 and February 2008 and between March 2009 and March 2010 at the Parque Estadual do Itacolomi, Brazil. 
Table I. Total number of individuals and number and average of the cubed intertegular distance of the females and males of Megachile (Moureapis) maculata obtained in trap nests in the Parque Estadual do Itacolomi, Brazil

\begin{tabular}{|c|c|c|c|c|}
\hline \multirow[t]{2}{*}{ Individuals } & \multicolumn{2}{|c|}{ Male } & \multicolumn{2}{|c|}{ Female } \\
\hline & $n$ & Size $\left(\mathrm{mm}^{3}\right)(\bar{X} \pm \mathrm{SD})$ & $n$ & Size $\left(\mathrm{mm}^{3}\right)(\bar{X} \pm \mathrm{SD})$ \\
\hline 344 & 122 & $22.2 \pm 0.15$ & 73 & $23.54 \pm 0.30$ \\
\hline
\end{tabular}

During only 6 of the 27 months of the study were no nests built, indicating there is no dormancy in M. maculata. Adult emergence occurred from 3 to 9 weeks after the female closing the nest, with an average of 6 weeks (29\%). The nesting period of $M$. maculata was continuous, but the adult hatching of nests built during the dry season took longer ( 7 weeks on average) than those built during rainy season ( 5 weeks on average), but the difference was no significant $(U=23 ; P>0.05$; Figure 3$)$.

\subsection{Nest architecture}

Females of $M$. maculata constructed an average of 5.34 brood cells with a range of 1-11. The cell series were structured as the pattern commonly described for Megachile, built only with leaves, having a cylindrical appearance, and arranged in linear series. Each occupied trap consisted of only one nest. All nests were closed with circular leaf pieces $(5.81 \pm 0.46 \mathrm{~mm}, N=50)$, with a vestibular space between the nest entry and the outermost cell. When adults emerged, they chewed through the leaves capping each cell.

Females cut leaves in three different forms depending on usage: smaller and rounded - used as a base cell (Figure 4a); larger and rounded - used in operculation (Figure 4b); and elliptical — used to cover the side of the wall (where the mark made by powerful jaws of the females was clearly visible) (Figure 4c). The larger leaves used as side panels possessed an average length of $1.44 \pm 0.01 \mathrm{~cm}$ and an average width of $0.86 \pm 0.01 \mathrm{~cm}(N=242)$. There was no relationship between the length of cut pieces of leaves used in nests and the diameter of cavities $\left(F_{1,240}=0.1, P>0.05\right)$ and width $\left(F_{1,240}=1.3, P>0.05\right)$.

After the construction of a cell with cut pieces of leaves, the female lays a single egg over a mass of pollen, which is consumed during the larval stage (Figure 4d). Average length and diameter of

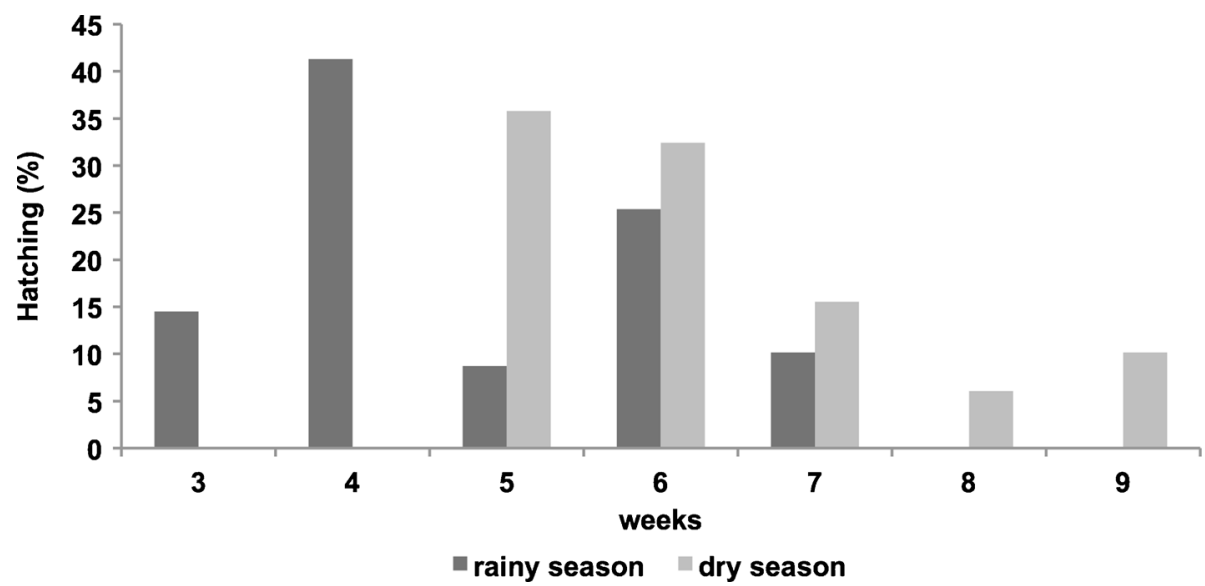

Fig. 3. Development time of Megachile (Moureapis) maculate collected through trap nests at the Parque Estadual do Itacolomi, Brazil, according to the season that the bee hatched in the laboratory. 
Table II. Generalized linear models (GLMs) constructed with body mass of male and female of Megachile (Moureapis ) maculata obtained in trap nests in the Parque Estadual do Itacolomi, Brazil, and explanatory variables tested

\begin{tabular}{lrllcrr}
\hline Explanatory variable & $d f$ & Dev. Resid. & $d f$ & Dev. Resid. & \multicolumn{1}{l}{$F$} & $P$ \\
\hline Sex & 1 & 0.8927 & 193 & 0.56401 & 308.5068 & $P<0.05$ \\
Month & 15 & 0.06022 & 178 & 0.50380 & 1.3873 & $P>0.05$ \\
Sex/month & 12 & 0.0234 & 166 & 0.48035 & 0.6753 & $P>0.05$ \\
\hline
\end{tabular}

Significant results have $P<0.05$

female brood cells $(\bar{X}=11.16 \pm 0.24 \mathrm{~mm}, \bar{X}=$ $6.22 \pm 0.09 \mathrm{~mm}, N=18)$ were significantly greater than those of male brood cells $(\bar{X}=9.29$ $\pm 0.14 \mathrm{~mm}, N=18, \bar{X}=5.45 \pm 0.1 \mathrm{~mm}, N=18$ ) $\left(F_{1,35}=46.02, P<0.05\right.$ and $F_{1,35}=35.15$; $P<0.05$, respectively).

Field observations and morphological comparisons revealed that females of $M$. maculata used leaves of two species of Fabaceae, Senna pendula (Humb. \& Bonpl. ex Willd.) H.S. Irwin \& Barneby and Dalbergia miscolobium Benth., and that they did not use flower petal fragments.

\subsection{Natural mortality}

The overall mortality rate was $26 \%$, with only $5 \%$ being due to unknown factors. Eighteen brood cells $(21 \%)$ were attacked by three species of natural enemies: the cuckoo bee Coelyoxis
(Acrocoelioxys) sp. was present throughout the sampling period and attacked 13 brood cells (7.31\% of the total brood cells); the parasitoid wasp Melittobia australica Girault, 1912 (Eulophidae) attacked 1 brood cell $(0.22 \%$ of the total brood cells); and the cuckoo wasp Chrysis sp. parasitized 4 brood cells $(1.94 \%$ of the total brood cells).

\section{DISCUSSION}

We describe here in detail the natural history of a leafcutting bee $M$. maculata since little of the information about the nests of M. maculata acquired in this study had been previously described by Sabino and Antonini (2011) that reported on this species using trap nests and Cardoso and Silveira (2012) that described some aspects of its nesting biology. Cardoso and Silveira (2012)

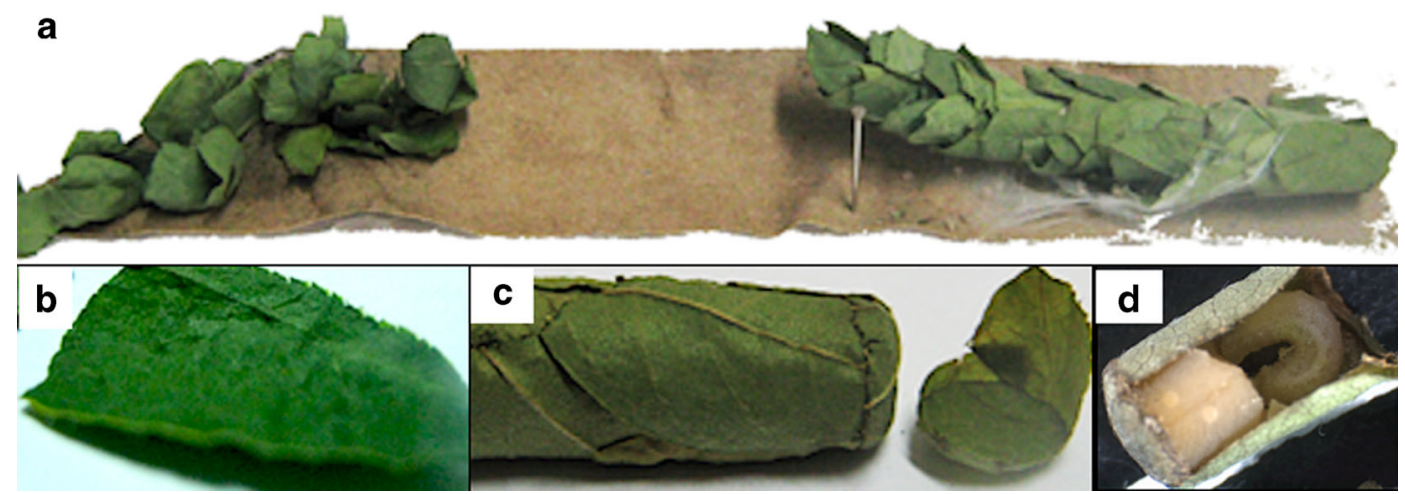

Fig. 4. Nest of Megachile (Moureapis) maculata, showing the presence of circular pieces of leaves at the entrance, with the protection function of the brood cells, shapes of leaf, and nest architecture: a smaller leaf and rounded, forming the base of the cell; $\mathbf{b}$ bigger leaf and rounded, used to close the nest; $\mathbf{c}$ an elliptical leaf, used on the side of the cells; $\mathbf{d}$ open nest of Megachile (Moureapis) maculata, showing the nest architecture and the presence of a larva. 
speculated that the limited number of nests they found may be a result of $M$. maculata being rare in the specific environment they studied (semideciduous forest) or that this bee species does not use the bamboo culms as trap nests (that, in general, mimic wood). Contrary to this, however, our results show $M$. maculata to be abundant in semi-deciduous forest, nesting in trap nests made of tubes. It is important to notice that only this species of bee was nesting in trap nests offered in 2 years of research.

In general, our observations on the nesting biology of M. maculata is in agreement with what is known for the few other studied species of Megachile (Moureapis) (e.g., Buschini et al. 2009; Sabino and Antonini 2011; Cardoso and Silveira 2012) and described (Krombein 1967) for other leafcutter bee species (e.g., Laroca et al. 1987; Zillikens and Steiner 2004; Torretta et al. 2012). Specifically, all these studies reported the use of pre-existing cavities, a layer of overlapped pieces of leaves covering the entire chamber and an inner layer of pieces of leaves with the bottom of the brood cells formed by bending leaf pieces upwards from the base of the brood cells (Medler 1965; Kim 1992).

The use of leaves of different groups of plants seems to be a pattern in Megachile species and is related to the availability of plants with "soft" leaves, which are easier to cut and mold (Zillikens and Steiner 2004; Alqarni et al. 2014). We found M. maculata using leaves of two species of Fabaceae for lining nests. Other studies have reported the use of other plant families, such as Zillikens and Steiner (2004) who found nests of Megachile pseudanthidioides Moure, 1943 built with pieces of fern (Pteridophyta) and leaves of Myrtaceae. Some species, however, use leaves of the plant where they collect pollen, such the alfalfa leafcutter bee, Megachile rotundata Fabricius, 1787 that uses leaves of alfalfa for lining its nests (Pitts-Singer and Bosch 2010). This does not occur with $M$. rotundata that preferably uses Asteraceae plants as source of pollen (Sabino et al. 2016).

The average number of brood cells found in the present study was similar to that reported by Cardoso and Silveira (2012) for Megachile (Moureapis) benigna, but greater than what they reported for $M$. maculata, perhaps due to the limited number of nests they analyzed. There were also noticeable differences between these reports and the present study regarding the number and size of the leaf pieces used for cell construction. These variations are likely due to differences in body size of the distinct species, with larger bees having larger brood cells.

The hatching pattern of M. maculata at our study site suggests a multivoltine life cycle. Various generations of individuals, mostly developing without interruption in brood cells, were found between about June to January. Adults hatch about 45 days after egg laying. However, a small proportion of bees stay in an "optional" diapause in the dry season, emerging after 60 days. Wilms (1995) also recorded a seasonal pattern of activity for megachilids associated with the summer in the Atlantic Forest of Boraceia, São Paulo. According to Camarotti-de-Lima and Martins (2005), many megachilid bees from tropical regions are bi- or multivoltine. Despite a lot of studies conducted in many parts of the world, more species of leafcutting bees, particularly from the tropical region, need to be studied over a wider range of climates and biomes to assess whether megachilids generally pass part of the year in diapause.

Nesting activity throughout all seasons in the present study was not expected, since most other studies have found the concentration of nesting activity to be associated with the warm season (Becker et al. 1991; Alves-dos-Santos 2003). Some authors (e.g., Viana et al. 2001) considered that such activity peaks are associated with food availability. M. maculata is oligolectic on Asteraceae (Sabino et al. 2016), and the two most important pollen sources for this species (Baccharis and Vernonia species) bloom in both the dry and wet seasons, which may explain the lack of seasonality for this bee species.

The male-biased sex ratio we found differed from that observed by Filho and Garófalo (2016) for Megachile (Crysosauros) guaranitica and by Cardoso and Silveira (2012) for M. benigna, but was similar to the male-biased ratio found by Cardoso and Silveira (2012) for M. guaranitica. However, Megachile sex ratios can exhibit considerable intraspecific variation, as reported by Teixeira et al. (2011), who found a male-biased 
ratio for M. benigna, whereas Cardoso and Silveira (2012) observed a slightly female-biased ratio for the same species. For some species of Neotropical Megachile, both female-biased (Zillikens and Steiner 2004; Torretta et al. 2012, Filho and Garófalo 2016) and male-biased sex ratios (Sabino and Antonini 2011; Marques and Gaglianone 2013) have been found. The reasons for differences in sex ratio for species of Megachile remain very speculative, and this interesting issue is in need of more study. Cardoso and Silveira (2012), for example, pointed out that Megachile (Moureapis) may actually prefer to use wide cavities (they used $3 \mathrm{~cm}$ ) based on a few observations for two species. In our study, however, we offered four different sizes of trap nests and $M$. maculata predominantly used traps of $0.9 \mathrm{~mm}$. The selection of cavity size differs among species that nest in pre-existing cavities.

The body mass was not related to food availability, as was suggested by Michener (1974), Krombein (1967), and Kim (1997). Therefore, to be consistent, a study intending to evaluate the mechanisms that drive sex allocation should take into account foraging time, number of trips required to construct a cell, and quantity of pollen allocated according to sex. Anyway, we should be more careful when analyzing sex ratio data. Our study used pre-defined diameters with pretty large differences between the single diameter classes. It is difficult to reliably study sex ratios when the female bees cannot choose from a broad and continuous range of nest diameters, as it would be the case when using reed or bamboo for trap nests.

Mortality of larvae due to mold or desiccation was low along the entire study period. Among the parasitoid species that may attack the brood cells, Coelioxys spp., M. australica (Eulophidae), and the cuckoo wasp, Chrysis spp., are known to parasitize nests of Megachile and other bee species (e.g., Michener 1953; Zillikens and Steiner 2004; 2003; Pitts-Singer and Cane 2011; Filho and Garófalo 2016). Brood parasitism of leafcutting bees by species of Coelioxys is well documented worldwide, including Brazil (Krombein 1967; Michener 2000; Scott et al. 2000; Aguiar et al. 2005; Cardoso and Silveira 2012), supporting our findings. The overall rate of parasitism was $20.7 \%$, similar for trap nesting
Hymenoptera in tropical and subtropical regions (between 10 and 20\%; e.g., Paini 2004; Torretta et al. 2012; Alvarez et al. 2016) with some notable exceptions (e.g., 49\% in O'Neill and O'Neill 2016, 76.9\% in Filho and Garófalo 2016, and only $3 \%$ in Staab et al. 2014). The synchrony of the life cycles of kleptoparasitic bees and their hosts was previously described by Scott et al. (2000) and Zillikens and Steiner (2004). In our study, the development of Coelioxys sp. and M. maculata was of similar duration so that the emergence of this kleptoparasite was synchronized with that of its hosts. At least for the single short brood cycle observed, the emergence of the kleptoparasites closely corresponded to the lifetime of the host. Zillikens and Steiner (2004) pointed out that if Coelioxys sp. was strictly specific to its Megachile host, parasitism should also occur during the second brood cycle. This was exactly what we found; the kleptoparasitic bee was found throughout the study period showing the same life cycle pattern as their host.

The use of black cardboard tubes has a potential use in the management of this species for pollination programs. Where farming is intense, and an abundance of pollinating bees is needed, management of cavity nesting bees would be valuable (Pitts-Singer and Bosch 2010). The oligolecty in Asteraceae makes M. maculata a potential pollinator for important crops in Brazil such Helianthus annuus L., for example. Sunflower is the second largest source of eatable oil in the world and depends almost exclusively on the non-native honey bees (Paiva et al. 2003). Furthermore, Megachile has been seen as a good pollinator of Vellozia in high-altitude rocky grasslands (Oliveira et al. 1991; Jacobi and del Sarto 2007).

According to Bosch (2008) and Torreta et al. (2012), basic knowledge about the nesting biology, including developmental physiology of bee pollinators, is essential for developing appropriate rearing methods to be applied in pollination of cultivated plant species. Taking into account those considerations and based on our results, we can say that there is future potential for developing this species for pollination of cultivated plants in Brazil. Further research on this diverse group of bees is needed and will shed more light on the role of Megachile species as pollinators. 


\section{ACKNOWLEDGEMENTS}

The authors wish to thank Gabriel Melo for the identification of $M$. maculata, Maria Cristina T.B. Messias (DEBIO-UFOP) for the identification of the leaves of the plant types, the staff at Parque Estadual do Itacolomi-IEF that allowed the access to study at the area, the "Fundação de Amparo à Pesquisa do Estado de Minas Gerais-FAPEMIG," and Conselho Nacional de Pesquisa, CNPq, for granting a scholarship to the authors. We also wish to thank the two anonymous reviewers for useful comments and suggestions that improved the manuscript.

Contributions Both authors conceived the research, analyzed the data, and wrote the paper.

Architecture du nid, cycle biologique et ennemis naturels de l'abeille coupeuse de feuille néotropicale Megachile (Moureapis) maculata (Hymenoptera : Megachilidae) dans une forêt de montagne

Forêt atlantique/ sex ratio/ abeille solitaire/ nid-piège/ Brésil

Nestarchitektur, Lebenszyklus und natürliche Feinde der neotropischen Blattschneiderbiene Megachile (Moureapis) maculata (Hymenoptera: Megachilidae) in eine Bergregenwald

Atlantischer Regenwald/ Geschlechterverhältnis/ Nisthilfen/ Brasilien

\section{REFERENCES}

Aguiar, C. M. L., Garófalo, C. A., Almeida, G. F. (2005) Trap-nesting bees (Hymenoptera, Apoidea) in áreas of dry semideciduous Forest and caatinga, Bahia, Brazil. Rev. Bras. Zool. 22 (4), 1030-1038

Alqarni, A. S., Hannan, M. A., Gonzalez, V. H., Engel, M. S. (2014) Nesting biology of the leafcutting bee Megachile minutissima (Hymenoptera: Megachilidae) in central Saudi Arabia. Ann. Entomol. Soc. Am. 107(3), 635-640

Alvarez, L. J., Lucia, M., Aquino, D. A., Ramello, P. J., Abrahamovich, A. H. (2016) Nesting biology and associated insect enemies of the exotic leaf cutter bee Megachile (Eutricharaea) concinna (Hymenoptera: Megachilidae) in Argentina. J. Apic. Res. 54 (4), 305-313

Alves-dos-Santos, I. (2003) Trap-nesting bees and wasps on the university campus in São Paulo, Southeastern
Brazil (Hymenoptera: Aculeata). J. Kans. Entomol. Soc. 76 (2), 328-334

Ascher, J. S., Pickering, J. (2015) Discover life bee species guide and world checklist (Hymenoptera: Apoidea: Anthophila). Discover Life, University of Georgia, USA. http://www.discoverlife.org $/ \mathrm{mp} / 20 \mathrm{q}$ ? guide= Apoidea_species (Accessed on 11 Sept 2016)

Becker, P., Moure, J. S., Peralta, F. J. A. (1991) More about euglossine bees in amazonian forest fragments. Biotropica. 23 (4), 586-591

Bosch, J. (2008) Production of undersized offspring in a solitary bee. Anim. Behav. 75 (3), 809-816

Bullock, S. H. (1999) Relationships among body size, wing size and mass in bees from a tropical dry forest in Mexico. J. Kansas Entomol. Soc. 72(4), 426-439.

Buschini, M. L. T., Rigon, J., Cordeiro, J. (2009) Plants used by Megachile (Moureapis) sp. (Hymenoptera: Megachilidae) in the provisioning of their nests. Braz. J. Biol. 69(4), 1187-1194

Camarotti-de-Lima, M. F., Martins, C. F. (2005) Biologia de nidificação e aspectos ecológicos de Anthodioctes lunatus (Smith) (Hymenoptera: Megachilidae, Anthiidini) em área de tabuleiro nordestino, PB. Neotrop. Entomol. 34(3), 375380

Cane, J. H. (1987) Estimation of bee size using intertegular span (Apoidea). J. Kansas Entomol. Soc. 60, 145-147

Cardoso, F.C., Silveira, F. A. (2012) Nesting biology of two species of Megachile (Moureapis) (Hymenoptera: Megachilidae) in a semideciduous forest reserve in southeastern Brazil. Apidologie 43(1), 71-81

Crawley, M. J. (1993) GLIM for ecologists. Oxford: Blackwell Scientific Publications.

Eickwort, G. C., Matthews R. W., Carpenter, J. (1981) Observation on the nesting behaviour of Megachile rubi and M. texana with a discussion of the significance of soil nesting in the evolution of megachilid bees (Hymenoptera: Megachilidae). J. Kans. Entomol. Soc. 54(3), $557-570$

Filho, L. C. R, Garófalo, C. A. (2016) Nesting biology of Megachile (Chrysosarus) guaranitica and high mortality caused by its cleptoparasite Coelioxys bertonii (Hymenoptera: Megachilidae) in Brazil. Aust. Entomol. 55(1), 25-31

Genaro, J. A. (1996) Nest parasites (Coleoptera, Diptera, Hymenoptera) of some wasps and bees (Vespidae, Sphecidae, Colletidae, Megachilidae, Anthophoridae) in Cuba. Caribb. J. Sci. 32(2), 239-240

Jacobi, C. M., del Sarto, M. C. L. (2007) Pollination of two species of Vellozia (Velloziaceae) from high-altitude quartzitic grasslands, Brazil. Acta Bot. Bras. 21(2), 325-333

Kim, J. Y. (1992) Nest dimensions of two leaf-cutter bees (Hymenoptera: Megachilidae). Ann. Entomol. Soc. Am. 85(1), 85-90

Kim, J. Y. (1997) Female size and fitness in the leaf-cuter bee Megachile apicalis . Ecol. Entomol. 22(3), 275282 
Krombein, K. V. (1967) Trap-nesting wasp and Bees: life histories nest and associates. Smithsonian Press, Washington.

Laroca, S. (1991) Euglossa stellfeldi: arquitetura do ninho e coexistência com Pseudocentron apicipennis em uma mesma cavidade (Hymenoptera, Apoidea). Acta Biol. Par. 20(1), 103-108

Laroca, S., Filho, D. L. S., Zanella, F. C. V. (1987) Ninho de Austromegachile habilis e notas sobre a diversidade de Megachile (Apoidea, Megachilidae) em biótipos neotropicais. Acta Biol. Par. 16(1), 93-105

Marques, M. F., Gaglianone, M. C. (2013) Biologia de nidificação e variação altitudinal na abundância de Megachile (Melanosarus) nigripennis Spinola (Hymenoptera, Megachilidae) em um inselberg na Mata Atlântica, Rio de Janeiro. Biosci. J. 29(1), 198-208

Martins, R.P., Antonini, Y., Silveira, F.A., West, S. (1999) Seasonal variation in the sex ratio of a neotropical solitary bee. Behav. Ecol. 10(4), 401-408

Medler, J. T. (1965) A note on Megachile mendica Cresson in trap nests in Wisconsin (Hymenoptera: Megachilidae). Proc. Entomol. Soc. Wash. 67(2), 113-116

Messias, M. C. T. B., Dias, S. J., Roschel, M. B., Sousa, H. C., Matos, A. M. (1997) Levantamento florístico das matas e distribuição de algumas espécies endêmicas da área do Parque Estadual do Itacolomi. Relatório técnico UFOP/BIRD/IEF-PROFLORESTA, Universidade Federal de Ouro Preto, Ouro Preto. 75, 809-816

Michener, C. D. (1953) The biology of a leafcutter bee (Megachile brevis) and its associates. Univ. Kansas Sci. Bull. 35(1), 1659-1748

Michener, C. D. (1974) The Social Behavior of the Bees. Harvard University Press. Cambridge.

Michener, C. D. (2000) The Bees of the World. The Johns Hopkins Univ. Press, Baltimore. Maryland.

Morato, E. F. (2003). Biologia de Megachile (Austromegachile) orbiculata Mitchell (Hymenoptera, Megachilidae) em matas contínuas e fragmentos na Amazônia, in: Melo, G. A. R. and Alves-dos-Santos, I. Apoidea Neotropica: Homenagem aos 90 anos de Jesus Santiago Moure. Editora UNESC, Criciúma, pp. $157-162$

Morato, E. F., Martins, R. P. (2006) An overview of proximate factors affecting the nesting behavior of solitary wasps and bees (Hymenoptera: Aculeata) in preexisting cavities in wood. Neotrop. Entomol. 35(3), 285-298

Oliveira, R., Schlindwein, C. (2010) Experimental demonstration of alternative mating tactics of male Ptilothrix fructifera (Hymenoptera, Apidae) Anim. Behav. 80, 241-247

Oliveira, P. E., Gibbs, P. E., Bianchi, M. (1991) Pollination and breeding system of Vellozia squamata (Liliales: Velloziaceae): a species of the Brazilian cerrados. Bot. Acta. 104(5), 392-398

O’Neill, K. M., O’Neill, J. F. (2016) Brood Parasitism of the Resin Bee Megachile campanulae (Robertson) by
Coelioxys modesta Smith (Hymenoptera: Megachilidae). J. Kans. Entomol. Soc. 89(2), 117-127

Paini, D. R. (2004) Nesting biology of an Australian resin bee (Megachile sp.; Hymenoptera: Megachilidae): a study using trap nests. Aust. J. Entomol. 43(1), 10-15

Paiva, G. J., Terada, Y., de Toledo, V. D. A. A. (2003) Seed production and germination of sunflower (Helianthus annuus L.) in three pollination systems. Acta Sci. Anim. Sci. 25(2), 223-227

Peck, O. (1969) Chalcidoid (Hymenoptera) parasites of the alfafa leaf-cutter bee, Megachile rotundata, in Canada. Can. Entomol. 101(4), 418-422

Pitts-Singer, T., Bosch, J. (2010) Nest establishment, pollination efficiency, and reproductive success of Megachile rotundata (Hymenoptera: Megachilidae) in relation to resource availability in field enclosures. Environ. Entomol. 39(1), 149-158

Pitts-Singer, T. L., Cane, J. H. (2011) The alfafa leafcutting bee, Megachile rotundata: the world's most intensively managed solitary bee. Annu. Rev. Entomol. 56(1), 221-237

Raw, A. (2007) An annotated catalogue of the leafcutter and mason bees (Genus Megachile) of the Neotropics. Zootaxa 1601(1), 1-127

Sabino, W. O., Antonini, Y. (2011) Use of trap-nests with a Neotropical leaf-cutter bee Megachile (Moureapis) anthidioides (Hymenoptera: Megachilidae). J. Kans. Entomol. Soc. 84(1), 78-79

Sabino, W. O., Bastos, E. M. A., Antonini, Y. (2016) Trophic-niche of the leaf cutter bee Megachile (Moureapis ) maculate (Hymenoptera: Megachilidae) in southeastern Brazil. J. Kans. Entomol. Soc.

Scott, V. L., Kelley, S. T., Strickler, K. (2000) Reproductive biology of two Coelioxys cleptoparasites in relation to their Megachile hosts (Hymenoptera: Megachilidae). Ann. Entomol. Soc. Am. 93(4), 941-948

Staab, M., Ohl, M., Zhu, C-D., Klein, A-M. (2014) A Unique Nest-Protection Strategy in a New Species of Spider Wasp. PLoS ONE 9(7): e101592

Teixeira, F. M., Schwartz, T. A. C., Gaglianone, M. C. (2011) Biologia da nidificação de Megachile (Moureapis ) benigna Mitchell. EntomoBrasilis. 4(3), 92-99

Torretta, J. P., Durante, S. P., Colombo, M. G., Basilio, A. M. (2012) Nesting biology of the leafcutting bee Megachile (Pseudocentron) gomphrenoides (Hymenoptera: Megachilidae) in an agro-ecosystem. Apidologie 43(6), 624-633

Tscharntke, T., Gathmann, A., Steffan-Dewenter, I. (1998) Bioindication using trap-nesting bees and wasps and their natural enemies: community structure and interactions. J. Appl. Ecol. 35(5), 708-719

Tylianakis, J., Veddeler, D., Lozada, T., Lopez, R. M., Benítez, P., Klein, A. M., Koning, G. H. J., Olschewski, R., Veldkamp, E., Navarrete, H., Onore, G., Tscharntke, T. (2004). Biodiversity of land-use systems in coastal Ecuador and bioindication using trap-nesting bees, wasps, and their natural enemies. Lyonia 6(2), 7-15 
Veddeler, D., Tylianakis, J., Tscharntke, T., Klein, A. M. (2010). Natural enemy diversity reduces temporal variability in wasp but not bee parasitism. Oecologia 162(3), 755-762

Viana, B. F., Silva, F. O., Kleinert, A. M. (2001) Diversidade e sazonalidade de abelhas solitárias (Hymenoptera: Apoidea) em dunas litorâneas no nordeste do Brasil. Neotrop. Entomol. 30(2), 245-251

Wilms, W. (1995). Die Bienenfauna im Küstenregenwald Brasiliens und ihre Beziehungen zu Blütenpflanzen: Fallstudie Boracéia, São Paulo. Universität Tübingen. Tübingen, PhD Dissertation

Yanega, D. (1994) Nests and hosts of three species of megachilid bees (Hymenoptera: Apoidea:
Megachilidae) from Coahuila, México. J. Kans. Entomol. Soc. 67(4), 415-417

Zillikens, A., Steiner, J. (2004) Nest architecture, life cycle and cleptoparasite of the neotropical leaf-cutting bee Megachile (Chrysosarus) pseudanthidioides Moure (Hymenoptera: Megachilidae). J. Kans. Entomol. Soc. 77(3), 193-202

Zuo, J., Cornelissen, J. H., Hefting, M. M., Sass-Klaassen, U., van Logtestijn, R. S., van Hal, J., Goudzwaard, L., Liu, J. C., Berg, M. P. (2016) The (w)hole story: Facilitation of dead wood fauna by bark beetles? Soil Biol. Biochem. 95(1), 70-77 